\section{Siirtymäkoneiston kriittinen luenta}

Kristiina Brunila \& Lisbeth Lundahl (toim.) (2020). Youth on the Move. Tendencies and Tensions in Youth Policies and Practicies. Helsinki University Press. 200 sivua.

NUORTEN SIIRTYMÄT koulutusjärjestelmän sisällä ja koulutuksesta työelämään ovat nuorisopolitiikan keskeisiä huomion kohteita, ovat olleet jo pitkään. Kouluttamattomat ja työelämään kiinnittymättömät nuoret nähdään yhteiskunnallisena ongelmana, johon on vastattava esimerkiksi ohjauksin, sanktioin, houkuttimin, ohjelmin, horisontaalisin strategioin, yksilövalmennuksin ja moniammatillisin työottein.

Koulutuksen ja työelämän ulkopuolisuus nähdään enenevässä määrin syrjäytymisenä. Tämä ilmiö rakentaa periaatteellisen yhteyden niin nuorisopolitiikan ja koulutuspolitiikan kuin nuorisotutkimuksen ja kriittisen koulutustutkimuksen välille.

\section{POLITIIKKATOIMIEN LÄPIVALAISU}

Kahden professorin, Kristiina Brunilan ja Lisbeth Lundahlin, kokoama teos yhdistää samoihin kansiin koulutuspolitiikan ja sen käytäntöjen tutkimuksen, nuorisotutkimuksen ja koulutussosiologian näkökulmia. Tutkimusten aineistoa on kerätty Suomesta, Ruotsista, Islannista ja Englannista. Artikkelikokoelma tarkastelee kriittisesti siirtymiin liittyvien politiikkatoimien ja käytäntöjen kokonaisuutta, siirtymäkoneis- toa. Siirtymiä koskevaa nuorisopolitiikkaa voi tarkastella nuoriin kohdistuvana hallinnointina, jossa yksilön oletetaan omaksuvan erilaisia minän tekniikoita.

Tekstit läpivalaisevat politiikkatoimia, niitä perustelevia diskursseja ja niitä käytäntöjä, joita nuoriin kohdistetaan. Artikkelit purkavat eri tavoin siirtymien yksilöä vastuuttavaa lähtökohtaa ja siihen liittyvää huomion kiinnittämistä psykologisiin prosesseihin ja valmiuksiin, instrumentalismia ja koulutuksen käytäntöjen unohtamista. Kasvatustieteellisessä tutkimuksessa tätä on kutsuttu dekontekstualismiksi. Erityisesti teoksen toimittajat tuovat esille sitä nuorisotutkimuksellista lähtökohtaa, että olennaista siirtymäkoneen toiminnan ymmärtämiseksi on tarkastella nuorten itsensä käsityksiä ja asenteita sen lisäksi, että tarkastellaan politiikkatoimia.

Teoksen ansiona voi pitää sen silloittavaa luonnetta ja tapaa yhdistää nuorisotutkimuksen näkökulmaa koulutuksen kriittiseen tarkasteluun. Teos on ankkuroitu teoreettisesti perusteltuun käsitykseen niistä tieto- ja valtarakenteista, jotka vastuuttavat yksilöä, lisäävät paineita kehittää itsetuntoa ja tuottavat dekontekstualismia. Monille, mutta ei kaikille, teoksen artikkeleille keskeisenä viitekohtana on filosofi Michel Foucault. Kuten

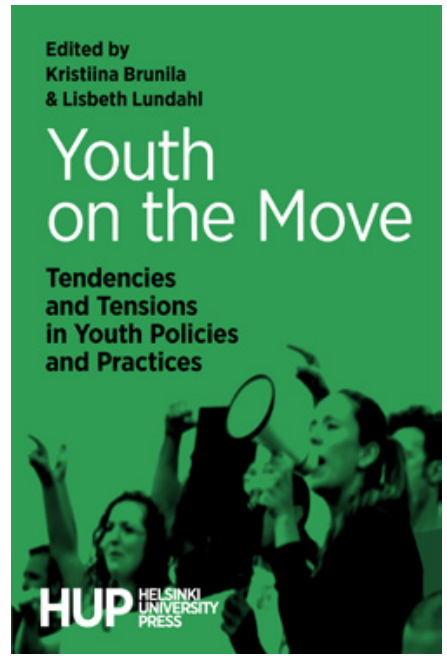

monille kriittisille tutkimuksille on tyypillistä, teos on kiinnostuneempi kritisoimaan vallitsevaa kuin tarjoamaan sille vaihtoehtoisia käytännön toteutusmalleja.

\section{SIIRTYMÄKONEISTON} PURKAMINEN

Teos koostuu kahdeksasta artikkelista, päätössanoista ja johdannosta. Ilahduttavasti teokseen on haluttu artikkeleita, joiden teoreettiset, metodologiset ja käsitteelliset lähtökohdat poikkeavat toisistaan. Kaksi artikkelia hyödyntää kvantitatiivista dataa ja edustaa perinteistä koulutussosiologian lähestymistapaa. Niissä osoitetaan vanhempien taustojen, kuten koulutustason, vaikuttavan heidän lastensa koulutukseen ja työllistymiseen. Muut tekstit ovat laadullisia ja hyödyntävät joko nuorten haastatteluja, etnografiaa tai koulutuspoliittisten dokumenttien diskursiivista luentaa. Vaikka teos itsessään on jo laaja, jäin kaipaamaan taideperusteisia 
menetelmiä tai otetta, jossa nuorilla itsellään on osallisuutta tutkimuksen toteutukseen.

Artikkelikokoelman ala on lavea, samoin näkökulma tarkasteltuun ilmiöön. Kokoomateoksille tyypilliseen tapaan artikkeleiden välillä on vaihtelua, ja ajoittain lukija joutuu erinomaisesti ajatellusta ja kirjoitetusta johdannosta huolimatta kamppailemaan nähdäkseen eri tekstejä yhdistävät tematiikat.

Itse hahmotan kirjan tehtäväksi osoittaa eritasoisten ilmiöiden välisiä suhteita. Yhtäältä tarkastellaan koulutusjärjestelemää kokonaisuutena ja osoitetaan, että se uusintaa yhteiskunnassa olevia eriarvoisia rakenteita. Käytännössä koulutusjärjestelmän ja yhteiskunnallisen mallitarinan näkökulmasta poikkeavaa koulutuspolkua kulkevat määrittyvät sinne muiden kuin henkilökohtaisten ominaisuuksiensa mukaan, sillä koulutus ei pura taustan vaikutusta. Tämä tietysti on tuttua koulutussosiologiansa lukeneille.

Kirjan arvo on kuitenkin sen pyrkimyksessä holistiseen otteeseen. Kun on osoitettu koulutusjärjestelmän tuottavan epäoikeudenmukaisuutta, voidaan tarkastella erilaisia pyrkimyksiä hallinnoida nuorten kouluttautumattomuutta tai sijoittumattomuutta työelämään. Hallinnointi tapahtuu erilaisten eetosten kautta ja kohdentuu yksilöön samalla tuottaen poliittisia rakenteita. Näiden ohella kirjassa tarkastellaan, miten nuoret itse neuvottelevat suhdettaan niin koulutusjärjestelmään ja vallitseviin eetoksiin kuin sitä, miten he suhtautuvat heihin kohdennettuihin toimiin.

Arvokkainta onkin se, miten teos pyrkii yhdistämään eri näkökulmat ja näin tehdessään riisuu neutraaliuden, välineellisyyden ja hyvien tarkoitusten peitteen siirtymäkoneen yltä. Se erittelee laajoja makrotason prosesseja, koulutusjärjestelmää, erilaisia hallinnan tekniikoita ja sitä, miten nämä kaikki näyttäytyvät nuorille, joiden on asetuttava osaksi heihin kohdistuvaa hallintoa. Kirja työstää kysymystä nuorten toimijuuden ja heihin kohdistuvan makrotason hallinnon välisestä suhteesta tavalla, joka ei typistä monimutkaisia kysymyksiä yksinkertaisiksi vastauksiksi.

\section{NYKYISYYDEN KYSYMINEN}

Onnistuneimpana tekstinä pidän Kristiina Brunilan, Katariina Mertasen ja Sari Mononen BatistaCostan artikkelia "Economic Worries - Therapeutic Solutions?". Kirjoittajat yhdistävät kiinnostavalla tavalla toisiinsa kolmen eri tutkimuksen reflektion. He osoittavat, että siirtymiä hallinnoidaan yrittäjämäisellä ja terapeuttisella hallintatavalla. Koulutuspolitiikka siis tukee yrittäjämäisten minuuksien kehittämistä, jotka vuorostaan kytkeytyvät yksilöiden erilaisiin tapoihin rakentaa itse omaa emotionaalista ja psykologista hyvinvointiaan.
Empiirisessä osiossaan kirjoittajat tarkastelevat diskursiivisesti, miten hallinnan terapeuttisuus ja yrittäjämäisyys heijastuu nuorten itsensä käsityksiin ihanneminuuksista. Artikkeli osoittaa lyhyessä tilassa tehokkaasti, miten diskursseilla rakennetaan minuuksia ja miten ne vaikuttavat nuoriin. Päätelmää ei kuitenkaan tulkita mekaanisesti, vaan teksti säilyttää ajattelun dynaamisuuden.

Teos tarkastelee enemmän siirtymäkoneiston koulutusjärjestelmää koskevia ulottuvuuksia kuin työllisyyspalveluita tai koulutuksen ulkopuolisia ohjauspalveluita, kuten alle 30-vuotiaille tarkoitettuja Ohjaamo-pisteitä tai työelämävalmennuksia. Siksi se ei yksinään pura siirtymäkoneistoa, ja moni koneiston osa jää vielä kriittisen tarkastelun ulkopuolelle.

Teoksen eittämätön ansio on kuitenkin sen halussa rakentaa siltoja eri tutkimusperinteiden välille. Näkökulmien yhdistämisen tavoite on problematisoida itsestään selvänä pidettyä ja osoittaa, miten yhteiskunnassa kyseenalaistamaton asioiden tila tuotetaan. Näin tehdessään kirja on Michel Foucault'n termein nykyisyyden ontologiaa, eli erittelee, millainen on oma ajankohtamme ja siellä mahdollisten kokemusten alue.

\section{TOMI KIILAKOSKI}

FT, dosentti, vastaava tutkija Nuorisotutkimusseura 